\title{
Exechesops leucopis Jordan, 1928 (Coleoptera: Anthribidae) an exotic oriental fungus weevil in Europe
}

\section{Exechesops leucopis Jordan, 1928 (Coleoptera: Anthribidae) - экзотический ориентальный можнослоник в Европе}

\author{
N.N. Yunakov ${ }^{1} \&$ V.V. Terekhova ${ }^{2}$ \\ H.H. Юнаков ${ }^{1}$, В.В. Терехова ${ }^{2}$
}

\footnotetext{
${ }^{1}$ Natural History Museum, University of Oslo, P.O. Box 1172, Blindern NO-0318, Oslo, Norway. E-mail: n.yunakov@gmail.com

${ }^{2}$ Museum of Nature, Kharkiv National University, Trinklera str. 8, 61022 Kharkiv, Ukraine. E-mail: t_viktoria@mail.ru
}

KEY WORDS: Anthribidae, Exechesops leucopis, fauna of Russia, fauna of Ukraine, hill-topping, stridulation behavior.

КЛЮЧЕВЫЕ СЛОВА: Anthribidae, Exechesops leucopis, фауна России, фауна Украины, хиллтоппинг, стридуляция.

ABSTRACT: Exechesops leucopis Jordan, 1928, initially known from Eastern and South-Eastern Asia, was discovered in natural forests of South European Russia and Ukraine since 1975. Acer tataricum and $A$. campestre are suggested to be its host plants in Europe. Observation of the beetles revealed hill-topping and elytro-tergal stridulation behavior in females.

PЕЗЮМЕ: Exechesops leucopis Jordan, 1928, изначально известный из Восточной и Юго-Восточной Азии, отмечался в естественных лесах Юга европейской части России и Украины начиная с 1975. Предполагаемыми кормовыми растениями в Европе являются Acer tataricum and A. campestre. У Exechesops leucopis впервые зарегистрированы хиллтоппинг (hilltopping) и элитро-тергальная стридуляция.

\section{Introduction.}

Anthribidae is quite large family of weevils comprising about 3860 species from 371 genera [Rheinheimer, 2004]. The species in majority are termophilic and inhabit tropical, basically forest, belt of the Earth. Temporal belts significantly poor but south-eastern part of Palaearctic highlighted by reach anthribid fauna. There is very few species having transpalearctic or holarctic range. The genus Exechesops Schönherr, 1847 belonging to predominantly Ethiopian-Indo-Malayan tribe $\mathrm{Zi}$ gaenodini, comprises the species with very unusual sexual dimorphism resulted in hypertrophic male head with huge interocular width and eyes distantly divided apart, situated on lateral processes of head capsule. Exechesops species occur basically in South-Eastern Palaearctic and North Indo-Malayan Regions, one species described from SE Africa. E. leucopis Jordan, 1928 is only species widespread far to the north in Palearctic region [Frieser, 1995; Egorov, 1996]. Since 1970s in ZIN collection in material from European Russia this species was undetermined or mistakenly considered in the genus Dissoleucas Jordan, 1925 as unidentified species. Although the elytro-tergal stridulation device is absent among anthribid species studied so far [Lyal \& King, 1996] the stridulation is documented for several cases including Exechesops (orig. data).

\section{Material and Methods.}

All specimens studied are housed in the KUMN Museum of Nature, Kharkiv National University (Kharkiv, Ukraine) and ZIN — Zoological Institute (St. Petersburg, Russia).

Sampling of alive material and preliminary field observations were done in primary natural deciduous forest along the Seversky Donets river nearby the Biological Station of Kharkiv National University (KUBS, N49 36'52" E36 19 '12"; $150 \mathrm{~m}$ a.s.1.) by 8-12.VII.2008. Adults were collected on/under Acer tataricum, the tree is presumed to be the host of E. leucopis, by sweep net or beating kit. Observations of alive beetles were done mostly in vitro (KUBS labor of entomology) and partly in the field at 14.00-7.00 PM within 7 days. For the observation beetles were kept apart and together in breeding cage under natural condition. Woody breeding cage with net walls $(40 \times 40 \times 40 \mathrm{~cm})$ contained fresh brunch of Acer tataricum and 1 pair (both sexes) of beetles. Another pair was kept in $25 \mathrm{~cm}^{3}$ glass vial.

Results and discussion

Exechesops leucopis Jordan, 1928

Figs 1-4

= Exechesops foliatus Frieser, 1995

= Exechesops elenae Egorov, 1996

MATERIAL. Russia: $1 \sigma^{\prime \prime}$ (ZIN) Voronezh Prov., Ramon' town env., 4.VI.1975; 2 우 (ZIN) Volgograd Prov., $10 \mathrm{~km} \mathrm{~S}$ of Mikhailovka Vill., Medveditsa Riv., N49 58 $45^{\prime \prime}$ E43 $12^{\prime} 28^{\prime \prime}$, flood land forest,

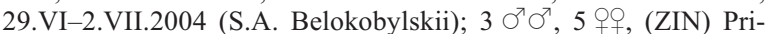
morskiy Kray, Vladivostok env., Sputnik station, 4314'23" N 

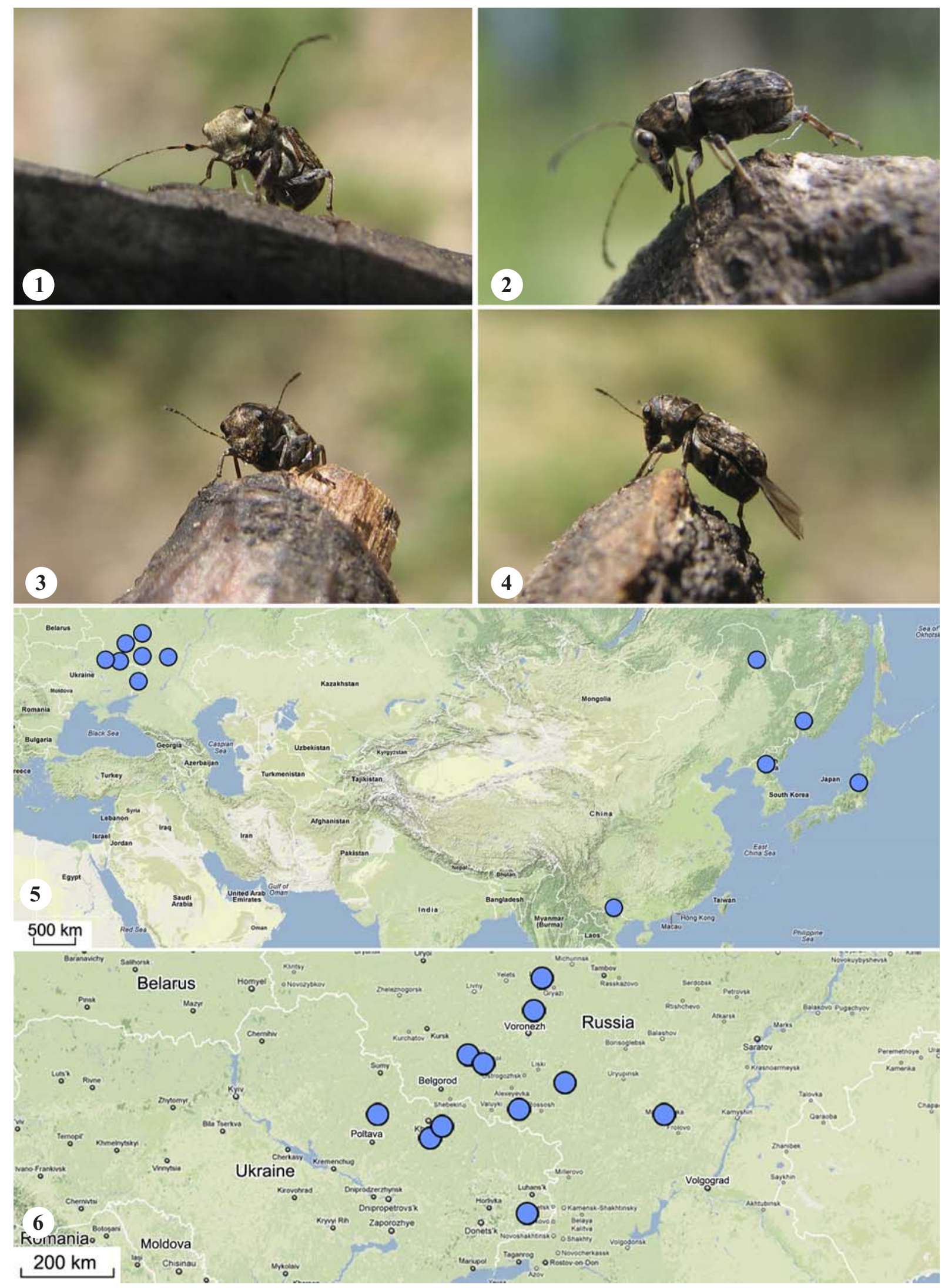

Figs 1-6. Exechesops leucopis Jordan: 1-2 - male; 3-4 - female; 5 - general distribution; 6 - distribution in Europe.

Рис. 1-6. Exechesops leucopis Jordan: 1-2 - самец; 3-4- самка; 5 - общее распространение; 6 - находки в Европе. 

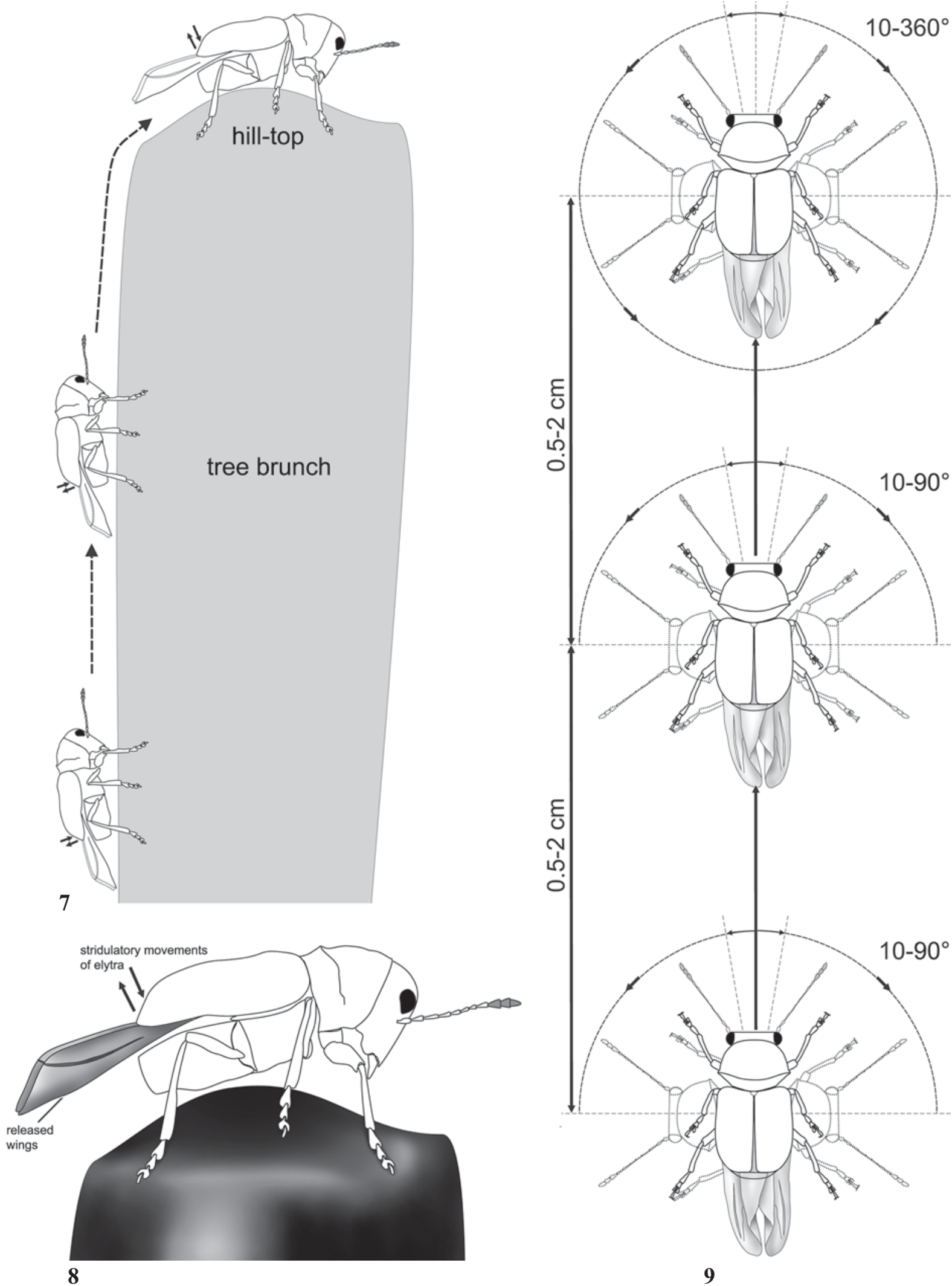

Figs 7-9. Behavior of Exechesops leucopis Jordan: 7 - hill-topping; 8 - stridulation; 9 - scheme of female "dance"; rotations indicated by interrupted circle and semicircle with arrows; extreme positions of body highlighted by interrupted contour.

Figs 7-9. Поведение Exechesops leucopis Jordan: 7 - хиллтоппинг; 8 - стридуляция; 9 - схема “танца” самки; вращение жука обозначено прерванными окружностью и полукружьями, крайнее положение тела - прерывистым контуром. 
132 $2^{\prime} 17^{\prime \prime}$ E, Ulmus-Alnus bush land, 28.VI.1978 (A.B. Egorov) Ukraine: Poltava Prov.: $23 \sigma^{7} \sigma^{7}, 11$ 우 (KUMN) Kotelva, Vorskla riv. bank, 50 $4^{\prime} 48^{\prime \prime} \mathrm{N} 34^{\circ} 42^{\prime} 21^{\prime \prime} \mathrm{E}, 100 \mathrm{~m}$, flood land, nemoral forest, on Acer tataricum, 26.VI.2011 (V.V. Terekhova). Kharkiv Prov.: $1 \sigma^{7}, 1$ ( 1 (KUMN) $7 \mathrm{~km} \mathrm{~S}$ Zmiev, Gaidary vill. env., N49 $36^{\prime} 52^{\prime \prime}$ E $36^{\circ} 19^{\prime} 12^{\prime \prime}$, 8.VII.2008, $150 \mathrm{~m}$ a.s.l. (V.V. Terekhova); $11 \bigcirc^{7} \sigma^{\prime}, 5$ 우 (KUMN) Eskhar vill. env., N4947' $3^{\prime \prime} \mathrm{E} 36^{\circ} 34^{\prime} 41^{\prime \prime}$, nemoral forest, 5.V.2001 (Yu. Skrylnik); $3 \sigma^{7} \sigma^{7}, 4$ + 90 (KUMN) Eskhar vill. env., N49॰47'3" E36 ${ }^{\circ} 34^{\prime} 41^{\prime \prime}$, on Acer campestre, 24.VII.2002 (N.N. Yunakov); Lugansk Prov.: 1 (KUMN) Antraci distr., D’yakovo vill., N4757'3" E398'25", 23.IX.2006 (S. Konovalov); $1 \mathrm{O}^{7}$ (KUMN), Antracit distr., Orekhovoye vill., N48 ${ }^{\circ}$ '59" E399'40", 23.IX.2006 (S. Konovalov).

RECORDS. Russia: Belgorod [Kovalenko, 2010], Lipetsk [Tsurikov, 2009], Voronezh*, Volgograd Prov.*, Amursky Kray, Primorsky Kray, South of Khabarovsk Kray; NE China; Japan: Honshu, Kyushu, Tsushima Is.; Korea; Vietnam [Frieser, 1995; Egorov, 1996; Legalov, 2002, 2010; Kim, 2012].

BEHAVIORAL NOTES. Adults are diurnal. The females initialize stridulatory movements of elytra at 5.00-6.00 PM when males nearby appeared. Stridulation may be fragmented into the following 3 stages: (1) female releases metathoracic wings which are partly folded along the longitudinal axis; (2) elytra are getting up slightly but remain closed; (3) rapid dorso-ventrally movements of abdominal segments are started that causes mutual friction of pygidial and elytral stridulatory surfaces and stridulation effect (Fig. 8). Each stridulatory act is continued for ca. 1-3 seconds and then female moves ahead for $0.5-2 \mathrm{~cm}$ and turns by $10-90^{\circ}$ left/right. Most of the stridulatory acts and $10-360^{\circ}$ rotations occurred while females reached a hill-top (Figs 7, 9).

Preliminary observations revealed (1) hill-topping and stridulation behavior in females, (2) both males did nothing while females stridulated and "danced".

HOST PLANTS. Styrax japonica, S. obassia, Acer ginnala [Egorov, 1996]. In Ukraine it feeds on dry or rotten branches of Acer tataricum and $A$. campestre.

DISTRIBUTION. Ukraine, South of European Russia; Far East of Russia, NE China, Korea, Japan, Vietnam (Figs 5-6).

Preliminary analyzed original material and available records reveal this species inhabits natural deciduous forests along large rivers, where it normally living on dry or rotten branches and inside the aggregations of Acer spp. fruits. The fact that E. leucopis emerges in the entomological material from East Europe only since 1970s suggested this species might be accidently introduced with cultivated species of decorative garden trees and shrubs from Far East, China, Korea or Japan. On the other hand it is always collected strictly in the natural forests and we do not know any cases it was collected in planted areas, urban parks or gardens that suggests E. leucopis may be a native species in Europe.

ACKNOWLEDGEMENTS. The authors thank B.A. Korotyaev (ZIN, St. Petersburg) for supplying the material and R.V. Filimonov (Russian Entomological Society, St. Petersburg) for informational support. The work of the first author was supported by research grant of the St. Petersburg Administration: PSP \# 070004 and by DFG (Deutsche Forschungsgemeinschaft) research grant: KL 1162/4-1.

\section{References}

Egorov A.B. 1996. [Family Anthribidae] // P.A. Ler (ed.). Opredelitel nasekomykh Dal'hego Vostoka Rossii. Vol. 3. Coleoptera. Part 3. Vladivostok: Dal'nauka. P.166-199 [in Russian].

Frieser R. 1995. Neue und bemerkenwerte Anthribiden aus der indomalaiischen Region (Coleoptera: Anthribidae) // Acta coleopterologica. München. Vol.11 No.1. P.13-48.

Legalov A.A. 2002. Cheklist of weevils of Family Nemonychidae, Urodontidae, Rhynchitidae, Attelabidae and Brentidae (Coleoptera, Curculionoidea) from Asian part of Russia // Zhivotnyi mir Dalnego Vostoka. Vol.4. P.105-116.

Legalov A.A. 2010. Annotated checklist of species of superfamily Curculionoidea (Coleoptera) from Asian part of the Russia // Amurian zoological journal. Vol.2. No.2. P.93-132.

Lyal C.H.C., King T. 1996. Elytro-tergal stridulation in weevils (Insecta: Coleoptera: Curculionoidea) // Journal of Natural History. Vol.30. P.703-773.

Kim Y.-J. 2012. The Beetles of Korea. http://www.beetleskorea.com/ [access 23.03.2012]

Kovalenko Ya.N. 2010. [Material on the fauna of fungus weevils (Coleoptera: Anthribidae) of subfamilies Choraginae and Anthribidae of the south of Middle-Russian forest-steppe] // Eversmania. Vol.21-22. P.38-41 [in Russian].

Rheinheimer J. 2004. Illustrierter Katalog und Bibliographie der Anthribidae der Welt (Insecta: Coleoptera) // Mitteilungen des Entomologischen Vereins Stuttgart. Bd.39. P.3-242.

Tsurikov M.N. 2009. [The beetles of Lipetsk Province]. Voronezh: Voronezh State University Publishing-polygraphic center. 332 pp. [in Russian]. 